\title{
ANALISIS KEBERADAAN PG MADUKISMO TERHADAP KESEJAHTERAAN MASYARAKAT DESA TIRTONIRMOLO KABUPATEN BANTUL YOGYAKARTA
}

\author{
ANAL YSIS OF THE EXISTENCE OF PG MADUKISMO \\ ON THE WELFARE OF THE CITIZEN OF TIRTONIRMOLO VILLAGE, \\ BANTUL REGENCY, YOGYAKARTA
}

\author{
Jihan Marha*, Zumi Saidah, Pandi Pardian dan Rani Andriani Budi Kusumo \\ Program Studi Agribisnis Fakultas Pertanian Universitas Padjadjaran \\ Jl. Raya Jatinangor Sumedang Km. 21 \\ *E-mail: jihan16006@mail.unpad.ac.id \\ (Diterima 13-01-2020; Disetujui 20-01-2020)
}

\begin{abstract}
ABSTRAK
Agroindustri merupakan salah satu sektor yang diharapkan dapat meningkatkan perekonomian masyarakat dalam suatu negara. Keberadaan agroindustri akan memberikan dampak positif terhadap masyarakat yang berada disekitarnya. Dampak positif diantaranya membuka peluang berkerja, membuka peluang usaha baru dan kegiatan sosial kepada masyarakat. Tujuan dari penelitian ini untuk menganalisis hubungan persepsi dampak keberadaan Agroindustri PG Madukismo terhadap kesejahteraan masyarakat Desa Tirtonirmolo. Penelitian ini menggunakan desain pendekatan kuantitatif dan teknik survei pada suatu kasus. Analisis yang digunakan adalah uji validitas, uji realibilitas, analisis deskriptif, Uji Peringkat Man Whitney (U test), dan Uji Rank Spearman Correlation. Hasil penelitian ini menunjukan bahwa terdapat hubungan persepsi dampak keberadaan Agroindustri PG Madukismo terhadap kesejahteraan masyarakat Desa Tirtnirmolo.
\end{abstract}

Kata kunci: Dampak agroindustri, Kesejateraan masyarakat, PG Madukismo, Desa Tirtonirmolo

\section{ABSTRACT}

Agroindustry is one sector that expected to improve the economy of the people in a country. The existence of agro-industry will have a positive impact on the surrounding communities. Positive impacts include opening up employment opportunities, opening up new business opportunities and social activities to the community. The purpose of this study was to analyze the relationship between perception of the impact of the existence of PG Madukismo Agroindustry on the welfare of the citizen of Tirtonirmolo Village. This research uses a quantitative approach design and survey techniques in a case. The analysis used is the validity test, reliability test, descriptive analysis, Man Whitney Rank Test (U test), and Spearman Correlation Rank Test. The results of this study indicate that there is a correlation between the perception of the impact of the existence of PG Madukismo Agroindustry on the welfare of Tirtonirmolo Village community.

Keywords: Impact of agroindustry, Community welfare, PG Madukismo, Tirtonirmolo Village

\section{PENDAHULUAN}

Indonesia adalah salah satu negara yang masih dalam keadaan berkembang. Pernyataan tersebut dapat didukung dari segi demografis, kependudukan yang sangat banyak serta masalah-masalah yang terjadi baik dalam hukum, pertanahan, sosial maupun ekonomi. Di balik hal tersebut, Indonesia memiliki sumber daya alam yang berlimpah. Hal 
tersebut menjadi berharga dalam mendukung pembangunan perekonomian negara. Menurut Adam Smith dalam Suryana (2000) yang berjudul Ekonomi Pembangunan: Problematika dan Pendekatan, bahwa pembangunan ekonomi adalah suatu proses yang memadukan dua kegiatan antar pertumbuhan penduduk dengan kemajuan teknologi.

Menurut Todaro (2000) bahwa pembangunan ekonomi adalah sebuah proses dalam peningkatan pendapatan suatu penduduk dalam jangka panjang. Pembangunan ekonomi dapat dilihat dari tingkat pertumbuhan PDB di tingkat nasional dan PDRB di tingkat wilayah. Indonesia merupakan salah satu negara yang sedang dalam proses pembangunan ekonomi berbasis sektor selain pada sektor pertanian yaitu sektor industri. Hal ini didukung dengan Undang-undang Nomor 3 Tahun 2014 tentang tujuan diselengarakannya perindustrian, yang berisi: a) mewujudkan industri nasional sebagai pilar dan pengerak perekonomian nasional, b) membuka kesempatan berusaha dan perluasan kesempatan kerja,

c) meningkatkan kemakmuran dan kesejahteraan masyarakat secara berkeadilan, dan d) tujuan lainnya.
Selain hal tersebut juga terjadi pada pertumbuhan ekonomi di Provinsi Daerah Istimewa Yogyakarta menggunakan data PDRB Atas Dasar Harga Berlaku Menurut Lapangan Usaha (Juta Rupiah), 2014-2018 menggambarkan sektor industri merupakan sektor terbesar yang memberikan kontribusi pada PDRB selain dari sektor pertanian. Salah satunya yaitu sektor industri non migas atau sering disebut Agroindustri. Sektor agroindustri dari tahun 2014-2018, setiap tahunnya terus mengalami peningkatan, sehingga dapat menjadi tombak pengerak dalam pembangunan ekonomi Provinsi DIY.

Umumnya sektor industri dapat memberikan dampak dan pengaruh terhadap kesejahteraan atau kondisi kepada pihak lain. Begitu pula dengan Provinsi Daerah Istimewa Yogyakarta, diharapkan dengan adanya industri dapat membantu pemerintahan kota/kabupaten dalam meningkatkan pendapatan masyarakatnya. Peningkatan pendapatan dapat dilihat dari upah minimum regional daerah tersebut. Nilai UMR kota/kabupaten DIY saat ini terlihat pada Tabel 1. 
Tabel 1. Upah Minimun Regional Daerah Istimewa Yogyakarta 2019

\begin{tabular}{lll}
\hline No & Daerah & Jumlah \\
\hline 1 & Kota Yogyakarta & Rp 1.846.400,00 \\
2 & Kabupaten Sleman & Rp 1.701.000,00 \\
3 & Kabupaten Bantul & Rp 1.649.800,00 \\
4 & Kabupaten & Rp 1.613.200,00 \\
& Kulonprogo & \\
5 & Kabupaten & Rp 1.571.000,00 \\
& Gunungkidul &
\end{tabular}

Rata-rata UMR DI
Yogyakarta

Sumber: Website resmi Daerah Istimewa Yogyakarta, 2019

Berdasarkan Tabel 1 rata-rata

Upah Minimum Regional di DI

Yogyakarta sebesar $\mathrm{Rp}$ 1.676.280,00.

Lima daerah utama di DI Yogyakarta,

UMR Kabupaten Bantul merupakan salah satu daerah yang masih memiliki jumlah UMR dibawah jumlah rata-rata, yaitu sebesar Rp 1.649.800,00, sehingga perlu adanya sektor yang dapat meningkatkan pendapatan masyarakat Kabupaten Bantul selain dari sektor pertanian. Sektor tersebut salah satunya adalah sektor agroindustri. Salah satu agroindustri yang terdapat pada Kabupaten Bantul yaitu PG Madukismo. Perusahan ini berkembang pada agroindustri berbasis komoditas tebu dalam memproduksi gula yang dikelola dengan profesional juga inovatif di Yogyakarta. PG Madukismo memiliki jumlah sumber daya manusia yang banyak, sehingga perusahaan ini dapat membuka peluang bekerja bagi masyarakat sekitarnya. Jumlah sumber daya manusia pada tahun 2019 digambarkan pada Tabel 2.

Tabel 2. Jumlah Karyawan PG Madukismo, Yogyakarta

\begin{tabular}{llll}
\hline Jenis Karyawan & $\begin{array}{l}\text { Jumlah } \\
\text { (orang) }\end{array}$ & $\begin{array}{l}\text { Sub } \\
\text { total } \\
\text { (orang) }\end{array}$ \\
\hline $\begin{array}{l}\text { Karyawan } \\
\text { Tetap }\end{array}$ & $\begin{array}{l}\text { Karyawan } \\
\text { Pimpinan }\end{array}$ & 60 & 377 \\
& $\begin{array}{l}\text { Karyawan } \\
\text { Pelaksana }\end{array}$ & 317 & \\
& KKWT & \pm 939 & \pm 3.939 \\
$\begin{array}{l}\text { Karyawan } \\
\text { Tidak } \\
\text { Tetap }\end{array}$ & $\begin{array}{l}\text { Borongan } \\
\text { Tebangan } \\
\text { dan Garap }\end{array}$ & \pm 3.000 & \\
& Kebun & & \\
&
\end{tabular}

\begin{tabular}{ll}
\hline Total & $\pm \mathbf{4 . 3 1 6}$ \\
\hline Sumber: PT Madubaru (2007)
\end{tabular}

Menurut Badan Pusat Statistika (2019) menyatakan bahwa industri masuk dalam kategori besar ketika banyaknya tenaga kerja $\geq 100$ orang. Melihat Tabel 2 maka PG Madukismo masuk dalam kategori sebuah industri besar, yang mana memiliki jumlah tenaga kerja lebih dari 100 orang. PG Madukismo memiliki SDM \pm 4.316 yang artinya perusahaan ini menyerap tenaga kerja yang sangat banyak.

Perseroan Terbuka ini juga memiliki program-program sosial untuk membantu meningkatkan perekonomian dan taraf kesejahteraan masyarakat. Program sosial yang dilakukan oleh PG Madukismo yaitu Program Kemitraan 
dan Bina Lingkungan (PKBL). Program ini sudah dilaksanakan sejak tahun 1991 yang terbagi menjadi dua bagian. Pertama, Program kemitraan adalah program untuk meningkatkan usaha kecil agar dapat menjadi mandiri, tangguh dan berkembang dengan bantuan dana yang diberikan oleh PG Madukismo. Program kemitraan terbagi menjadi dua bentuk yaitu: 1) Pinjaman berupa modal kerja, investasi maupun pinjaman khusus, 2) Hibah yang terbagi menjadi dua bagian, yaitu manajerial berupa pelatihan dan pemasaran berupa pameran dan promosi produk unggulan.

Bagian kedua yaitu Program Bina Lingkungan adalah program yang dilaksanakan untuk membantu masyarakat dalam bidang sosial. Program bina lingkungan memiliki berbagai macam bentuk, diantaranya yaitu: a) bencana alam, b) pendidikan masyarakat, c) kesehatan masyarakat, pengembangan sarana dan prasarana umum, e) sarana ibadah, dan f) pelestarian alam.

Berdasarkan penelitian Andriani (2012) keberadaan agroindustri di suatu daerah akan berkontribusi dalam pertumbuhan ekonominya, karena dapat menyediakan lapangan pekerjaan dan meningkatkan pendapatan. Hal ini dapat terjadi pada PG Madukismo yang dapat memberikan dampak pada daerah di sekitarnya yaitu Desa Tirtonirmolo. Selain itu, penelitian yang dilakukan oleh Ayuningtias (2017) bahwa terdapat hubungan kesejahteraan masyarakat dengan dampak yang ditimbulkan dari industrialisasi pedesaan dengan pola nafkah industri dan non industri.

Berdasarkan uraian diatar, mendukung perlu adanya penelitian mengenai Analisis Keberadaan Agroindustri PG Madukismo terhadap kesejahteraan masyarakat Desa Tirtonirmolo, Kabupaten Bantul, Yogyakarta, dengan rumusan masalah pokok yang akan diteliti dalam penelitian ini adalah:

1. Bagaimana perbedaan tingkat kesejahteraan masyarakat Desa Tirtonirmolo yang bekerja dengan yang tidak bekerja pada PG Madukismo, Yogyakarta?

2. Bagaimana hubungan persepsi dampak keberadaan Agroindustri PG Madukismo terhadap kesejahteraan masyarakat Desa Tirtonirmolo?

\section{METODE PENELITIAN}

Objek penelitian menurut Spradley dalam Sugiyono (2012) merupakan suatu keadaan dalam sebuah sosial yang 
memiliki kumpulan 3 komponen yaitu pelaku (actor), tempat (place), aktivitas (activity) yang saling berinteraksi secara sinergis. Objek penelitian ini, yaitu masyarakat yang tinggal pada suatu desa yang menerima dampak akibat dari aktivitas Agroindustri PG Madukismo, Yogyakarta. Penelitian ini berlokasi pada Desa Tirtonirmolo, Kecamatan Kasihan, Kabupaten Bantul, Derah Istimewa Yogyakarta dan Agroindustri PG Madukismo, Yogyakarta.

Desain penelitian yang digunakan yaitu pendekatan kuantitatif. Teknik yang dilakukan pada penelitian ini dengan melakukan survei pada suatu kasus. Variabel penelitian ini yaitu persepsi dampak positif Agroindustri PG Madukismo yang terbagi menjadi 3 variabel yaitu: a) membuka peluang bekerja di PG Madukismo, b) membuka peluang usaha baru dan c) kegiatan sosial terhadap masyarakat. Variabel selanjutnya yaitu kesejahteraan masyarakat.

Sampel didapatkan dengan munggunakan Rumus Slovin sebesar 69 responden dengan Proportionate Stratified Random Sampling yang menghasilkan sampel berjumlah 12 responden untuk masyarakat yang bekerja dan berjumlah 57 responden untuk yang tidak bekerja di PG Madukismo. Pengumpulan data dengan penggabungan 3 teknik yang disebut dengan trigulasi yaitu wawancara kepada responden dengan beberapa variabel, observasi dan kajian dokumen.

Uji instrumen penelitian menggunakan uji validitas dan uji reliabilitas. Hasil uji validitas didapatkan $\mathrm{R}_{\text {hitung }}>$ nilai $\mathrm{R}_{\text {tabel, }}$ sehingga rata-rata valiabel dinyatakan valid, selanjutnya dilakukan uji reliabilitas diperoleh nilai Cronbach Alpha $>$ nilai $\mathrm{R}_{\text {tabel }}$ pada seluruh instrument maka keputusannya reliabel. Tahap selanjutnya data yang didapatkan dari wawancara dilakukan analisis data. Matriks metode analisis dapat ditunjukan dalam bentuk Tabel 3.

Tabel 3. Matriks Metode Analisis Data

\begin{tabular}{|c|c|c|c|}
\hline No & Tujuan Penelitian & $\begin{array}{l}\text { Jenis } \\
\text { Data }\end{array}$ & $\begin{array}{l}\text { Metode } \\
\text { Analisis } \\
\text { Data }\end{array}$ \\
\hline 1 & $\begin{array}{l}\text { Menganalisis } \\
\text { perbedaan tingkat } \\
\text { kesejahteraan } \\
\text { masyarakat Desa } \\
\text { Tirtonirmolo yang } \\
\text { bekerja dengan } \\
\text { yang tidak bekerja } \\
\text { pada PG } \\
\text { Madukismo } \\
\text { Yogyakarta }\end{array}$ & $\begin{array}{l}\text { Data } \\
\text { primer }\end{array}$ & $\begin{array}{c}\text { Metode Uji } \\
\text { Peringkat } \\
\text { Man } \\
\text { Whitney } \\
\text { (U Test) }\end{array}$ \\
\hline 2 & $\begin{array}{l}\text { Menganalisis } \\
\text { hubungan dampak } \\
\text { keberadaan } \\
\text { Agroindustri PG } \\
\text { Madukismo } \\
\text { terhadap } \\
\text { kesejahteraan } \\
\text { masyarakat Desa } \\
\text { Tirtonirmolo }\end{array}$ & $\begin{array}{l}\text { Data } \\
\text { primer }\end{array}$ & $\begin{array}{c}\text { Metode Uji } \\
\text { Rank } \\
\text { Spearman } \\
\text { Correlation }\end{array}$ \\
\hline
\end{tabular}


HASIL DAN PEMBAHASAN

\section{Gambaran umum PG Madukismo}

PG Madukismo berdiri pada tahun 1955 yang dinaungi PT Madubaru yang terletak di Kabupaten Bantul, Provinsi Daerah Istimewa Yogyakarta. PT Madubaru terbagi menjadi dua bagian pengelolaan yaitu pabrik yang menghasilkan gula dengan nama Pabrik Gula Madukismo dan pabrik yang menghasilkan spiritus dengan nama Pabrik Spiritus Madukismo. PG Madukismo merupakan satu dari 17 Pabrik Gula yang berada di Provinsi DIY, namun 16 pabrik lainnya mengalami kehancuran pada masa Pemerintahan Jepang. PG Madukismo menjadi satusatunya pabrik gula yang masih berdiri hingga saat ini. Pabrik ini berlokasi di tengah Desa Tirtonirmolo, Kecamatan Kasihan, Kabupaten Bantul, Provinsi DI Yogyakarta.

PG Madukismo yang memiliki visi dan misi yang dijadikan sebagai acuan dalam menjalankan perusahaan ini.

\section{Visi}

Menjadikan PT Madubaru (PG/PS Madukismo) perusahaan Agroindustri yang unggul di Indonesia dengan menjadikan petani sebagai mitra sejati.

\section{Misi}

1) Menghasilkan Gula dan Ethanol yang berkualitas untuk memenuhi permintaan masyarakat dan industri di Indonesia.

2) Menghasilkan produk dengan memanfaatkan teknologi maju yang ramah lingkungan, dikelola secara profesional dan inovatif, memberikan pelayanan yang prima kepada pelanggan serta mengutamakan kemitraan dengan petani.

3) Mengembangkan produk/bisnis baru yang mendukung bisnis inti.

4) Menempatkan karyawan dan stake holders lainnya sebagai bagian terpenting dalam proses penciptaan keunggulan perusahaan dan pencapaian share holder values.

\section{Karakteristik Responden}

Menurut Badan Pusat Statistika (2015) rentang usia produktif dari umur 15 tahun hingga 64 tahun, namun dibagi menjadi dua kategori yaitu usia sangat produktif (15-49 tahun) dan usia produktif (50-64 tahun). Data umur responden terdapat pada Tabel 4.

Berdasarkan data pada Tabel 4 bahwa masyarakat yang bekerja mayoritas masuk dalam pada kategori 1549 tahun sebesar $75 \%$ yang artinya masih 
dalam kategori usia sangat produktif. Hal ini disebabkan karena PG Madukismo yang memiliki ketentuan batas umur untuk bekerja pada perusahaan tersebut. Saat umur sangat produktif ini, masyarakat dapat memaksimalkan kemampuannya untuk mencari nafkah dalam memenuhi kebutuhan keluarganya. Kesejahteraan akan terwujud ketika suatu keluarga dapat memenuhi kebutuhan seluruh anggota keluarganya $(\mathrm{BkkbN}$, 2011).

Tabel 4. Umur Responden

\begin{tabular}{ccccc}
\hline \multirow{2}{*}{ Umur (tahun) } & \multicolumn{2}{c}{ Bekerja } & \multicolumn{2}{c}{ Tidak Bekerja } \\
\cline { 2 - 5 } & $\mathrm{N}$ & $\%$ & $\mathrm{~N}$ & $\%$ \\
\hline $15-49$ & 9 & 75.00 & 19 & 33.33 \\
$50-64$ & 3 & 25.00 & 26 & 45.61 \\
$\geq 64$ & 0 & 0.00 & 12 & 21.05 \\
Total & $\mathbf{1 2}$ & $\mathbf{1 0 0 . 0 0}$ & $\mathbf{5 7}$ & $\mathbf{1 0 0 . 0 0}$ \\
\hline $\begin{array}{l}\text { Sumber: Data } \\
\text { Responden }\end{array}$ & Hasil & Wawancara & kepada \\
\end{tabular}

Responden yang tidak bekerja di PG Madukismo didominasi oleh masyarakat yang berumur pada kategori 50-64 tahun sebesar 45\%. Hal ini menggambarkan bahwa responden yang tidak bekerja memiliki umur dalam kategori usia produktif. Usia ini merupakan usia yang masih dapat menghasilkan pendapatan untuk keluarganya, namun kemampuannya sudah berbeda dengan usia pada kategori sangat produktif. Responden yang tidak bekerja di PG Madukismo pun terdapat $21 \%$ responden yang masuk dalam kategori $\geq 64$ tahun, yang artinya responden tersebut sudah masuk dalam usia tidak produktif, sehingga mereka sudah tidak mencari nafkah untuk keluarganya.

Menurut Kusumo (2009) Tingkat pendidikan yang terdapat pada wilayah tertentu akan memperlihatkan keragaman mata pencaharian yang dilakukan oleh penduduk wilayah tersebut. Pendidikan terakhir pada responden dalam penelitian ini yaitu disajikan pada Tabel 5 di bawah ini.

Tabel 5. Pendidikan Terakhir Responden

\begin{tabular}{lcccc}
\hline \multirow{2}{*}{$\begin{array}{c}\text { Pendidikan } \\
\text { Terakhir }\end{array}$} & \multicolumn{2}{c}{ Bekerja } & \multicolumn{2}{c}{ Tidak Bekerja } \\
\cline { 2 - 5 } & $\mathrm{n}$ & $\%$ & $\mathrm{n}$ & $\%$ \\
\hline SD & 0 & 0.00 & 16 & 28.07 \\
SMP & 0 & 0.00 & 9 & 15.79 \\
SMA/SMK & 5 & 41.67 & 23 & 40.35 \\
Perguruan & 7 & 58.33 & 9 & 15.79 \\
Tinggi & & & & \\
Total & $\mathbf{1 2}$ & $\mathbf{1 0 0 . 0 0}$ & $\mathbf{5 7}$ & $\mathbf{1 0 0 . 0 0}$
\end{tabular}

Sumber: Data Hasil Wawancara kepada Responden

\section{Berdasarkan Tabel 5 bahwa} pendidikan terakhir masyarakat desa yang bekerja di PG Madukismo berada pada mayoritas jenjang SMA/SMK dan jenjang perguruan tinggi. Karyawan di PG Madukismo yang dijadikan responden mayoritas adalah karyawan tetap, sehingga memiliki pendidikan 
terakhir minimal SMA/SMK karena hal tersebut syarat untuk menjadi karyawan tetap di PG Madukismo.

Berbeda dengan masyarakat yang tidak bekerja pada PG Madukismo, pendidikan terakhir yang dimiliki sangat beragam. Jenjang SMA/SMK menjadi jumlah tertinggi pada masyarakat yang tidak bekerja di PG Madukismo sebesar $40 \%$ dan jenjang SD menjadi indikator kedua terbanyak setalah SMA/SMK sebesar 28\%. Hal ini berkaitan dengan umur responden yang tidak bekerja di PG Madukismo, mayoritas pada usia produktif (50-64 tahun) bahkan banyak yang telah berumur $>64$ tahun, karena pada masa itu pendidikan belum menjadi prioritas yang utama dalam kehidupannya.

Umumnya semakin dekat jarak tempat tinggal dengan industri maka semakin besar pula dampak yang akan dirasakan oleh keluarga tersebut. Data jarak tempat tinggal responden menuju PG Madukismo disajikan dalam Tabel 6.

Tempat tinggal responden yang bekerja di PG Madukismo mayoritas masuk dalam indikator 300-500meter sebesar 50\%, yang artinya dekat dengan lokasi PG Madukismo. Hal ini disebabkan banyak responden yang menempati rumah dinas yang berada di sekitar PG madukismo.

Tabel 6. Jarak Tempat Tinggal menuju PG Madukismo

\begin{tabular}{|c|c|c|c|c|}
\hline \multirow{2}{*}{$\begin{array}{c}\text { Jarak } \\
\text { (meter) }\end{array}$} & \multicolumn{2}{|c|}{ Bekerja } & \multicolumn{2}{|c|}{ Tidak Bekerja } \\
\hline & $\mathrm{n}$ & $\%$ & $\mathrm{n}$ & $\%$ \\
\hline $300-500$ & 6 & 50.00 & 17 & 29.82 \\
\hline $501-1000$ & 1 & 8.33 & 18 & 31.58 \\
\hline $\begin{array}{l}1001- \\
1500\end{array}$ & 1 & 8.33 & 15 & 26.32 \\
\hline$>1501$ & 4 & 33.33 & 7 & 12.28 \\
\hline Total & 12 & 100.00 & 57 & 100.00 \\
\hline $\begin{array}{l}\text { Sumber: } \\
\text { Responde }\end{array}$ & $\overline{t a}$ & sil & & $\overline{k e p a d a}$ \\
\hline
\end{tabular}

Berbeda dengan masyarakat yang tidak bekerja di PG Madukismo yang setiap indikatornya memiliki jumlah yang hampir sama. Hal ini dikarenakan pengambilan responden yang dengan sengaja di ambil secara menyebar agar dapat mewakili dari setiap dusunnya dan mendapatkan informasi yang lebih beragam.

Karakteristik selanjutnya adalah pekerjaan responden. Umumnya semakin baik pekerjaan seseorang maka semakin baik pula kesejahteraan keluarganya. Hal ini berhubungan dengan pendapatan yang akan didapatkan oleh responden. Data pekerjaan responden disajikan dalam Tabel 7.

Responden dari masyarakat yang tidak bekerja di PG Madukismo mayoritas bekerja di swasta sebesar 52\%, jenis pekerjaan diantaranya memiliki 
usaha sendiri (wirausaha), karyawan perusahaan swasta, buruh pabrik, pengrajin dan lainnya. Responden yang bekerja menjadi petani hanya 5\%. Responden yang masuk dalam kategori lainnya sebesar 24\%. Hal ini berhubungan dengan karakteristik umur yang dimiliki oleh responden yang sudah bukan usia produktif sehingga responden sudah tidak bekerja (pensiunan) selain itu ibu rumah tangga dan pekerjaan serabutan masuk dalam kategori bekerja lainnya.

Tabel 7. Pekerjaan Responden

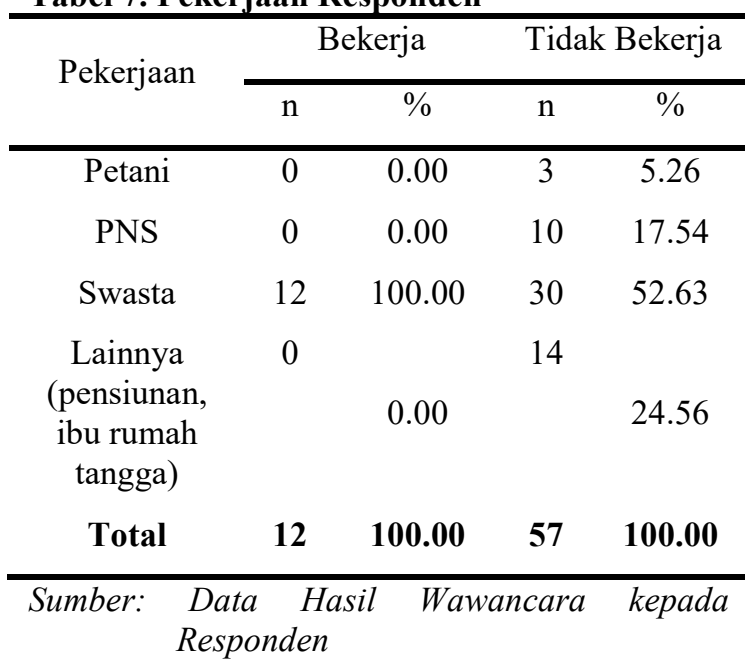

\section{Dampak Keberadaan PG Madukismo}

Penelitian ini membahas dampak positif keberadaan PG Madukismo yang dirasakan oleh masyarakat Desa Tirtonirmolo. Dampak positif keberadaan PG Madukismo terhadap masyarakat Desa Titronirmolo diwakilkan oleh tiga variabel yang telah disebutkan diawal.
Hasil data ketiga variabel ini dijumlahkan lalu dibagi menjadi dua kategori yaitu berdampak kecil dan berdampak besar. Persepsi responden terhadap dampak keberadaan PG Maduskismo dengan tiga variabel yang disajikan dalam bentuk grafik (\%) seperti pada Gambar 4.

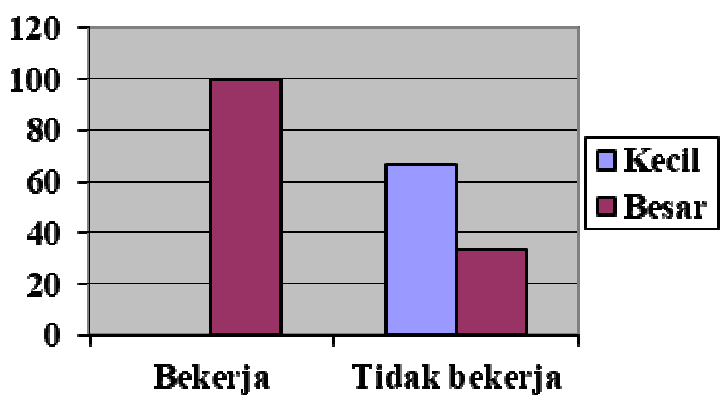

\section{Gambar 1. Persepsi dampak Keberadaan PG Madukismo terhadap Masyarakat}

Berdasarkan Gambar 4 menunjukan bahwa pada masyarakat Desa Tirtonirmolo yang bekerja pada PG Madukismo seluruh responden masuk dalam kategori besar yaitu sebesar 100\% responden. Hal ini karena masyarakat tersebut mengetahui kegiatan dan program-program yang miliki oleh $\mathrm{PG}$ Madukismo untuk membangun masyarakat. Responden yang tidak bekerja di PG Madukismo berjumlah hanya $33 \%$ orang yang masuk dalam kategori berdampak besar, 67\% masuk dalam kategori berdampak kecil. Hal ini diakibatkan oleh beberapa faktor salah satunya adalah jarak tempat tinggal dari lokasi PG Madukismo yang telah dibahas 
pada karakteristik Tabel 6. Selain itu, untuk melihat lebih dalam persepsi dampak keberadaan PG Madukismo akan dibahas pada setiap variabelnya.

\section{Membuka Peluang Bekerja di PG Madukismo}

Suatu perusahaan yang besar akan membutuhkan tenaga kerja yang besar juga. Dilihat pada Tabel 2 jumlah karyawan PG Madukismo, bahwa perusahaan ini masuk ke dalam kategori industri besar dengan jumlah karyawan \pm 4.316 orang. Hal ini berarti PG Madukismo memberikan peluang bekerja di PG Madukismo pada masyarakat sekitar. Ini artinya keberadaan PG Madukismo akan memberikan dampak positif kepada masyarakat. Persepsi masyarakat yang bekerja dengan masyarakat yang tidak bekerja di PG Madukismo pada Desa Tirtonirmolo dalam Tabel 8.

Tabel 8. Persepsi Responden terhadap Dampak Positif Keberadaan PG Madukismo berdasarkan Variabel Membuka Lapangan Pekerjaan

\begin{tabular}{lcccc}
\hline \multirow{2}{*}{$\begin{array}{l}\text { Lapangan } \\
\text { pekerjaan }\end{array}$} & \multicolumn{2}{c}{ Bekerja } & \multicolumn{2}{c}{ Tidak bekerja } \\
\cline { 2 - 5 } & $\mathrm{n}$ & $\%$ & $\mathrm{n}$ & $\%$ \\
\hline $\begin{array}{l}\text { Terbuka } \\
\text { lebar }\end{array}$ & 12 & 100 & 21 & 36.84 \\
$\begin{array}{l}\text { Tidak } \\
\text { terbuka } \\
\text { lebar }\end{array}$ & 0 & 0 & 36 & 63.16 \\
$\begin{array}{l}\text { Total } \\
\text { Sumber: }\end{array}$ & $\mathbf{1 2}$ & $\mathbf{1 0 0 . 0 0}$ & $\mathbf{5 7}$ & $\mathbf{1 0 0 . 0 0}$ \\
& Responden Hasil & Wawancara & kepada
\end{tabular}

Berdasarkan Tabel 8 dapat dilihat bahwa pada responden yang bekerja di PG Madukismo $100 \%$ responden menyatakan bahwa PG Madukismo memberikan dampak positif terbuka lebarnya peluang bekerja di PG Madukismo bagi masyarakat setempat. Hal ini berbeda dengan responden yang tidak bekerja di PG Madukismo sebesar 63\% masuk dalam kategori tidak terbuka lebar peluang lapangan pekerjaan. Hal ini karena masyarakat beranggapan bahwa tidak terdapatnya prioritas bagi masyarakat yang berada di sekitar perusahaan. Pernyataan tersebut juga sudah dikonfirmasi oleh karyawan tetap bagian sumber daya manusia, bahwa pada PG Madukismo ini tidak memberikan kesempatan/prioritas khusus kepada masyarakat yang tinggal di Desa Tirtonirmolo. Perusahaan ini juga masih menganut sistem nepotisme dalam perekrutan tenaga kerja, dimana tenaga kerja diambil dari kerabat/keluarga karyawan yang telah bekerja di PG Madukismo. Perusahaan juga tidak pernah mempublikasikan tentang pembukaan lowongan pekerjaan, karena setiap tahunnya selalu ada yang memasukan berkas lamaran untuk melamar kerja di PG Madukismo. Hal ini juga dilakukan karena rasa 
kepercayaan yang lebih tinggi kepada tenaga kerja yang memiliki hubungan keluarga/karyawan yang sudah bekerja di sana.

Banyak pekerjaan yang ada disana, namun pekerjaan yang paling banyak dibutuhkan oleh PG Madukismo adalah karyawan tidak tetap/musiman yang bekerja selama musim giling saja (6 bulan). Hal ini yang membuat masyarakat enggan bekerja disana karena perusahaan hanya mempekerjakan selama 6 bulan saja, sedangkan mereka akan merasa kesulitan mendapatkan pekerjaan di 6 bulan sisanya. Pekerjaan yang sering diperebutkan yaitu menjadi karyawan tetap namun untuk menjadi karyawan tetap tidak ada batasan waktu yang jelas untuk pengangkatannya. Ada karyawan yang sudah di angkat pada tahun ke 5 bekerja namun ada juga karyawan yang sudah 15 tahun bekerja baru diangkat menjadi karyawan tetap. Pengangkatan ini disesuaikan dengan kebutuhan perusahaan dan penilaian kinerja karyawan tersebut, sehingga para pemuda sudah jarang yang ingin bekerja disana. Masyarakat Desa Tirtonirmolo memiliki pekerjaan yang bermacammacam, seperti pengrajin, wirausaha, buruh pabrik maupun PNS.

\section{Membuka Peluang Usaha Baru}

Penelitian ini membahas kategori dampak positif keberadaan PG Madukismo terhadap masyarakat Desa Tirtonirmolo dengan variabel membuka peluang usaha. Maksudnya adalah terbukanya kesempatan membuka usaha yang berbeda dengan industri tersebut seperti pedagang kecil, toko ritel, penjual makanan dan lainya. Persepsi dampak positif keberadaan $\mathrm{PG}$ Madukismo dilihat dari variabel membuka peluang usaha baru disajikan dalam Tabel 9.

Tabel 9. Persepsi Responden terhadap Dampak Positif Keberadaan PG Madukismo berdasarkan Variabel Membuka Peluang Usaha

\begin{tabular}{lcccc}
\hline Peluang & \multicolumn{3}{c}{ Bekerja } & \multicolumn{2}{c}{ Tidak Bekerja } \\
\cline { 2 - 5 } Usaha & $\mathrm{n}$ & $\%$ & $\mathrm{n}$ & $\%$ \\
$\begin{array}{l}\text { Berpeluang } \\
\text { Tidak }\end{array}$ & 12 & 100 & 21 & 36,84 \\
berpeluang & 0 & 0 & 36 & 63,16 \\
\hline Total & 12 & 100,00 & 57 & 100,00 \\
\hline Sumber: & Data & Hasil & Wawancara & kepada \\
& Responden
\end{tabular}

Berdasarkan data tersebut terlihat bahwa karyawan yang bekerja di PG Madukismo menghasilkan 100\% menyatakan bahwa PG Madukismo memberikan dampak berpeluang untuk membuka usaha bagi masyarakat disekitarnya. Hal ini juga didukung dengan adanya pedagang-pedagang yang berjualan di halaman depan PG Madukismo setiap hari jumat yang dikenal dengan nama pasar kaget. 
Sekitar PG Madukismo pun merupakan jalan raya yang banyak pedagang berjualan disekitarnya. Saat musim giling banyak truk yang berdatangan setiap harinya untuk membawa tebu hasil tebang, sehingga menjadi target bagi usaha-usaha disekitarnya.

Responden yang tidak bekerja di PG Madukismo pada kategori tidak berpeluang membuka usaha baru sebesar $63 \%$, sedangkan untuk kategori berpeluang sebesar $37 \%$. Hal ini terjadi karena jarak tempat tinggal dari lokasi PG Madukismo yang telah dibahas pada karakteristik Tabel 6, dampak peluang usaha baru ini hanya dirasakan oleh beberapa dusun saja yaitu dusun yang berada di depan PG Madukismo, seperti Jogonalan Lor, Padokan Lor dan Kidul. Di luar dari 3 dusun tersebut tidak mendapatkan dampak tersebut. PG Madukismo juga memiliki tembok yang mengelilingi wilayah pabrik dan perumahan dinas, sehingga terpisah dengan masyarakat disekitarnya. Banyak masyarakat yang berpendapat bahwa dampak tersebut akan dirasakan jika kita tinggal di daerah depan perusahaan.

\section{Kegiatan Sosial kepada Masyarakat}

Setiap perusahaan memiliki program atau kegiatan sosial kepada masyarakat. Hal ini dilakukan untuk memberikan kebermanfaatan bagi masyarakat yang tinggal disekitarnya. Hal tersebut juga dimiliki oleh PG Madukismo yang telah dibahas pada latar belakang.

Penelitian ini dalam mengukur persepsi dampak positif keberadaan PG Madukismo salah satunya kegiatan sosial kepada masyarakat yang menjadi variabelnya. Persepsi masyarakat tehadap kegiatan sosial yang dilakukan oleh PG Madukismo yaitu disajikan oleh Tabel 10 yang memperlihatkan bahwa responden yang bekerja di PG Madukismo pada kategori berdampak besar berjumlah $100 \%$ responden. Hal ini disebabkan karena seluruh karyawan mengetahui bahwa PG Madukismo memiliki kegiatan sosial yang dikelola oleh bagian PKBL.

Tabel 10. Persepsi Responden terhadap Dampak Positif Keberadaan PG Madukismo berdasarkan Variabel Kegiatan Sosial terhadap Masyarakat

\begin{tabular}{|c|c|c|c|c|}
\hline \multirow{2}{*}{$\begin{array}{c}\text { Kegiatan } \\
\text { sosial }\end{array}$} & \multicolumn{2}{|c|}{ Bekerja } & \multicolumn{2}{|c|}{ Tidak bekerja } \\
\hline & $\mathrm{n}$ & $\%$ & $\mathrm{n}$ & $\%$ \\
\hline Berdampak & 12 & 100 & 45 & 78.95 \\
\hline $\begin{array}{l}\text { Tidak } \\
\text { berdampak }\end{array}$ & 0 & 0 & 12 & 21.05 \\
\hline Total & 12 & 100.00 & 57 & 100.00 \\
\hline
\end{tabular}


Responden yang tidak bekerja di PG Madukismo sebesar 79\% masuk ke dalam kategori berdampak dan $21 \%$ masuk ke dalam kategori tidak berdampak. Hal ini disebabkan karena PG Madukismo memberikan kegiatan sosial tidak kepada seluruh masyarakat Desa Tirtonirmolo melainnya hanya kepada beberapa masyarakat saja. Masyarakat tersebut seperti masyarakat kurang mampu, masyarakat yang sudah tua, anak yatim dan beberapa pihak yang membutuhkan. Selain itu, PG Madukismo juga memberikan bantuan melalui lembaga-lembaga desa seperti pembagian gula pada rumah ibadah, bantuan barang dan dana untuk kegiatankegiatan kepada karang taruna (Memperingati Maulid Nabi, Hari Kemerdekaan Indonesia dan lainnya), fasilitas-fasilitas yang dibutuhkan RTnya (balai pertemuan, tempat ibadah dan lainnya). Masyarakat tidak menyadari bahwa terdapat kegiatan-kegiatan sosial yang diberikan PG Madukismo secara tidak langsung.

Bantuan yang paling dirasakan adalah bantuan dalam meningkatkan fasilitas dusunnya seperti, memberikan lahan untuk membuat pendopo untuk pertemuan, memberikan lahan untuk tempat beribadah (gereja) dan banyak memberikan bantuan dalam kegiatan hari-hari spesial (panggung, kursi maupun sound system). Di luar dari bantuan tersebut, masyarakat masih banyak yang menyatakan bahwa kegiatan sosial yang di lakukan PG Madukismo belum sesuai dengan kebutuhan masyarakat. Banyak masyarakat yang mengharapkan perusahaan lebih peduli dengan keadaan lingkungan masyakarat di desa tersebut, seperti air yang telah tercemari oleh limbah ataupun udara yang tercemari oleh debu.

\section{Tingkat Kesejahteraan Masyarakat}

Menurut Marnelly masyarakat yaitu ketika manusia, kebudayaan dan lingkungannya saling berkaitan satu sama lain sehingga membuat satu kesatuan sebuah sistem. Kesejahteraan keluarga dapat diukur secara objektif melalui pendekatan yang baku, seperti ukuran yang ditentukan oleh Badan Koordinasi Keluarga Berencana Nasional (BKKBN) dan Badan Pusat Statistika (BPS). Variabel yang akan diukur tersebut adalah akses pendidikan, tingkat pendapatan, akses kesehatan dan kondisi perumahan serta fasilitas yang dimiliki oleh masyarakat. Tingkat kesejahteraan pada responden yang bekerja dan tidak bekerja di PG 
Madukismo yang disajikan dalam bentuk grafik (\%) pada Gambar 5.

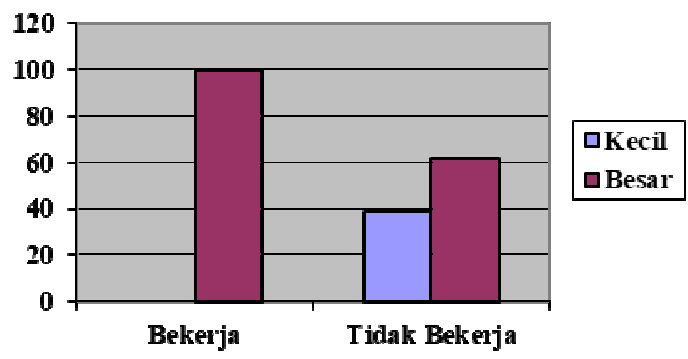

Gambar 2. Tingkat Kesejahteraan Masyarakat Desa Tirtonirmolo

Dilihat dari Gambar 5 responden yang bekerja maupun yang tidak bekerja memiliki mayoritas berada pada tingkat kesejahteraan tinggi $100 \%$ untuk responden yang bekerja dan $61 \%$ untuk responden yang tidak bekerja. Hal ini mengartikan bahwa kesejahteraan masyarakat Desa Tirtonirmolo sudah masuk dalam kategori tinggi.

Data yang didapatkan di lapangan diolah menggunakan Microsoft Excel 2007 dan uji statistik dengan SPSS. Dalam Siregar (2013) Uji peringkat bertanda Mann Whitney ( $U$ test) digunakan untuk menguji dua sampel independent (kedua sampel tersebut tidak saling mempengaruhi satu sama lain) dengan data berskala ordinal.

Hasil dari uji Uji Peringkat Mann Whitney (U test) didapatkan nilai Sig. 0.002. Syarat dari U test ketika Sig. > 0.05 maka terima $\mathrm{H}_{0}$, sedangkan ketika
Sig. $<0.05$ maka tolak $\mathrm{H}_{0}$ dan terima $\mathrm{H}_{1}$. Hasil uji ini didapatkan Sig. $0.002<0.05$ maka tolak $\mathrm{H}_{0}$ dan terima $\mathrm{H}_{1}$.

Kaidah pengujian terima $\mathrm{H}_{0}$, ketika $-Z_{\text {tabel }} \leq Z_{\text {hitung }} \leq Z_{\text {tabel }}$ hasil $\mathrm{U}$ test $Z_{\text {hitung }}$ sebesar -3.033, sedangkan $Z_{\text {tabel }}$ dengan $\alpha$ 0.025 yaitu sebesar 0.97 maka $-Z_{\text {tabel }} \geq Z$ hitung, yang artinya tolak $\mathrm{H}_{0}$ dan terima $\mathrm{H}_{1}$, yang artinya terdapat perbedaan tingkat kesejahteraan masyarakat Desa Tirtonirmolo yang bekerja dengan yang tidak bekerja pada PG Madukismo, Yogyakarta.

\section{Akses Pendidikan}

Pendidikan adalah salah satu modal dalam menjalani kehidupan bermasyarakat yang sangat penting. Adianty (2017) bahwa tingkat pendidikan mengalami perubahan setelah adanya sektor industri di desa tersebut. Akses Pendidikan merupakan kemampuan keluarga dalam menyekolahkan anakanaknya pada tingkat tertentu, jarak tempuh menuju sekolah, dan sumber biaya untuk menyekolahkan anaknya. Hasil variabel akses pendidikan dapat dilihat di Tabel 11.

Masyarakat yang bekerja dengan masyarakat yang tidak bekerja di PG Madukimo mayoritas berada pada kategori tinggi sebesar $83 \%$ dan 53\%. Responden pada penelitian ini banyak 
yang memiliki pendidikan yang masih rendah terutama pada responden yang tidak bekerja di PG Madukismo. Masih banyak yang hanya memiliki pendidikan terakhir ditingkat SD, SMP dan SMA, namun hal itu tidak membuat mereka melupakan pentingnya pendidikan bagi anak-anaknya. Dari hasil penelitian banyak sekali responden yang telah menyekolahkan anaknya hingga tingkat SMA/SMK, sedangkan untuk tingkat perguruan tinggi masih rendah.

Tabel 11. Kesejahteraan Masyarakat berdasarkan Variabel Akses Pendidikan

\begin{tabular}{lcccc}
\hline \multirow{2}{*}{$\begin{array}{c}\text { Akses } \\
\text { Pendidikan }\end{array}$} & \multicolumn{2}{c}{ Bekerja } & \multicolumn{2}{c}{ Tidak Bekerja } \\
\cline { 2 - 5 } & $\mathrm{N}$ & $\%$ & $\mathrm{n}$ & $\%$ \\
\hline Rendah & 2 & 16.67 & 27 & 47.37 \\
Tinggi & 10 & 83.33 & 30 & 52.63 \\
Total & $\mathbf{1 2}$ & $\mathbf{1 0 0}$ & $\mathbf{5 7}$ & $\mathbf{1 0 0}$ \\
\hline Sumber: & \multicolumn{2}{c}{ Data Hasil } & Wawancara & kepada \\
& Responden
\end{tabular}

Masyarakat yang bekerja di PG Madukismo kategori rendah sebesar 17\% sedangkan untuk masyarakat yang tidak bekerja di PG Madukismo pada kategori rendah sebesar 47\%. Mayoritas responden juga menyekolahkan anaknya jauh dari tempat tinggalnya saat ini, yaitu lebih dari $3 \mathrm{~km}$, karena fasilitas pendidikan yang berada di desa tersebut masih belum memadai. Hal ini yang menyebabkan kesejahteraan masyarakat dalam variabel akses pendidikan masih banyak yang masuk dalam kategori rendah.

\section{Tingkat Pendapatan}

Seseorang dapat dikatakan hidup layak ketika gaji/upah yang diterima dapat memenuhi seluruh kebutuhan dirinya sendiri maupun keluarganya, baik itu kebutuhan pangan, sandang, papan, pendidikan, kesehatan dan lainnya (Badan Pusat Statistika, 2015). Tingkat pendapatan yang diukur dalam penelitian ini adalah besarnya pendapatan yang diterima selama satu bulan. Data hasil penelitian tingkat pendapatan disajikan pada Tabel 12.

Tabel 12. Kesejahteraan Masyarakat berdasarkan Variabel Tingkat Pendapatan

\begin{tabular}{lcccc}
\hline \multirow{2}{*}{$\begin{array}{c}\text { Tingkat } \\
\text { Pendapatan }\end{array}$} & \multicolumn{2}{c}{ Bekerja } & \multicolumn{2}{c}{ Tidak Bekerja } \\
\cline { 2 - 5 } & $\mathrm{n}$ & $\%$ & $\mathrm{n}$ & $\%$ \\
\hline Rendah & 0 & 0 & 16 & 28.07 \\
Tinggi & 12 & 100 & 41 & 71.93 \\
Total & $\mathbf{1 2}$ & $\mathbf{1 0 0}$ & $\mathbf{5 7}$ & $\mathbf{1 0 0}$ \\
\hline
\end{tabular}

Sumber: Data Hasil Wawancara kepada Responden

Responden yang bekerja di PG Madukismo 100\% masuk dalam kategori tingkat pendapatan tinggi. Berbeda dengan responden yang tidak bekerja di PG Madukismo yang mayoritas masuk dalam kategori tinggi hanya sebesar $72 \%$ namun masih ada yang masuk dalam kategori rendah sebesar 28\%. Hal ini memperlihatkan masih ada masyarakat 
yang memiliki pendapatan dibawah dari

Upah Minimum Regional DIY. Responden yang memiliki pendapatan di bawah UMR berhubungan dengan Tabel 4 karakteristik umur responden yang di dominasi oleh responden yang sudah memiliki usia lanjut sehingga tingkat produktif kerjanya sudah menurun. Selain itu, Tabel 5 karakteristik pendidikan terakhir responden juga mempengaruhi pendapatan yang dihasilkan oleh masyarakat tersebut. Berjumlah 28\% responden hanya memiliki Pendidikan terakhir di tingkat SD dan mayoritas responden masih pada tingkat SMA/SMK sebesar $40 \%$, hal ini menjadi salah satu faktor masyarakat yang memiliki pendapatan rendah.

Menurut Simandjuntak dalam Puspas (2007) perbedaan tingkat pendapatan tidak hanya disebabkan oleh tingkat pendidikan saja, melainkan oleh faktor lainnya seperti keahlian, pengalaman kerja, jenis pekerjaan, sektor usaha dan tempat bekerja. Seperti pada Tabel 7 karakteristik pekerjaan responden yang memiliki upah di bawah UMR, terjadi karena pekerjaannya yang tidak menentu (serabutan) sehingga pendapatan yang dihasilkannya sering tidak menentu pula.
Berbeda dengan responden yang bekerja di PG Madukismo, karena pada perusahaan ini sudah menetapkan UMR dalam sistem mengupahan tenaga kerjanya dan memiliki PKB sebagai pengatur pemberian upah bagi karyawan tetapnya, sehingga responden yang bekerja di PG Madukismo terjamin dalam tingkat pendapatannya.

\section{Akses Kesehatan}

Subramanian (2004) kesehatan manusia adalah salah satu modal dalam menjaga kestabilan ekonomi. Manusia yang kurang sehat dapat menghambat dalam proses pembangunan ekonomi suatu negara. Penelitian Rahayu (2014) menghasilkan tidak adanya perubahan dari sebelum dan sesudah adanya sektor industri dengan presentasi 13,33\% untuk kategori akses yang sulit dan 86,67\% untuk kategori akses yang mudah. Akses masyarakat dalam memanfaatkan tenaga kesehatan dapat dilihat dari ketersediaan dan kemudahan masyarakat dalam mencapai fasilitas kesehatan tersebut. Penggolongan indikator pilihan untuk melakukan pengobatan yaitu, puskesmas, klinik/praktek dokter, dan pengobatan tradisional. Selain itu juga indikator dalam variabel ini adalah jarak menuju tempat sarana kesehatan, penyelanggara fasilitas kesehatan dan biaya untuk 
melakukan pengobatannya. Data hasil penelitian akses kesehatan masyarakat Desa Tirtonirmolo disajikan pada Tabel 13.

Tabel 13. Kesejahteraan Masyarakat berdasarkan Variabel Akses Kesehatan

\begin{tabular}{lcccc}
\hline \multirow{2}{*}{$\begin{array}{c}\text { Akses } \\
\text { Kesehatan }\end{array}$} & \multicolumn{2}{c}{ Bekerja } & \multicolumn{2}{c}{ Tidak Bekerja } \\
\cline { 2 - 5 } & $\mathrm{n}$ & $\%$ & $\mathrm{n}$ & $\%$ \\
\hline Rendah & 1 & 8.33 & 10 & 17.54 \\
Tinggi & 11 & 91.67 & 47 & 82.46 \\
Total & $\mathbf{1 2}$ & $\mathbf{1 0 0}$ & $\mathbf{5 7}$ & $\mathbf{1 0 0}$ \\
\hline $\begin{array}{l}\text { Sumber: Data } \\
\text { Responden }\end{array}$ & Hasil & Wawancara & kepada \\
& & & &
\end{tabular}

Hasil penelitian akses kesehatan baik pada masyarakat yang bekerja di PG Madukismo maupun yang tidak bekerja di PG Madukismo mayoritas masuk ke dalam kategori tinggi yang artinya responden merasa mudah dalam memanfaatkan fasilitas kesehatan yang tersedia. Akses kesehatan dalam kategori tinggi pada responden yang bekerja di PG Madukismo sebesar 91\% yang tidak jauh berbeda dengan responden yang tidak bekerja di PG Madukimo sebesar 82\%. Hal tersebut disebabkan karena untuk responden yang bekerja di PG Madukismo difasilitasi klinik yang dimiliki oleh PG Madukismo untuk seluruh tenaga kerjanya, baik karyawan tetap maupun karyawan tidak tetap. Sehingga karyawan dapat memanfaatkan fasilitas yang diberikan tanpa biaya/gratis yang artinya jaminan kesehatan ditanggung oleh perusahaan. Lokasi klinik PG Madukismo berada di sebelah lokasi perusahaan sehingga mudah dijangkau oleh para karyawan PG Madukismo.

Responden yang tidak bekerja di PG Madukismo dapat memanfaatkan akses kesehatan yang tersedia di Desa Tirtonirmolo. Desa ini memiliki fasiltas puskesmas yang tersedia untuk masyarakat sekitarnya. Puskesmas ini berada di tengah-tengah desa dan dekat dengan jalan raya sehingga sangat mudah dijangkau. Masyarakat juga dapat menggunakan BPJS untuk biaya pengobatanya. Hal tersebut yang menyebabkan responden yang tidak bekerja di PG Madukismo mayoritas masuk ke dalam kategori tinggi yang artinya akses kesehatan mudah dijangkau.

\section{Kondisi Perumahan serta Fasilitas yang Dimiliki}

Perumahan menjadi kebutuhan dasar yang harus dipenuhi oleh keluarga. Menurut Badan Pusat Statistika (2015) kualitas kesejahteraan rumah dicerminkan dari material rumah itu sendiri seperti jenis lantai, dinding, atap, dan fasilitas penunjang lainnya seperti sumber air, fasilitas MCK dan sumber penerangan. Indikator yang diukur dalam 
penelitian ini yaitu, kualitas rumah tinggal (atap, dinding dan laintai), status kepemilikan, fasilitas rumah tinggal (sumber air dan MCK) serta fasilitas lainnya (alat elektronik dan kendaraan) yang dimiliki. Hasil kesejahteraan masyarakat berdasarkan variabel kondisi perumahaan serta fasilitas yang dimiliki dapat dilihat pada Tabel 14.

Tabel 14. Kesejahteraan Masyarakat berdasarkan Variabel Kondisi Perumahan serta Fasilitas yang Dimiliki

\begin{tabular}{lcccc}
\hline \multicolumn{1}{c}{$\begin{array}{c}\text { Kondisi } \\
\text { perumahan } \\
\text { dan fasilitas }\end{array}$} & \multicolumn{2}{c}{ Bekerja } & \multicolumn{2}{c}{ Tidak Bekerja } \\
\cline { 2 - 5 } $\begin{array}{c}\text { yang } \\
\text { dimiliki }\end{array}$ & $\mathrm{n}$ & $\%$ & $\mathrm{n}$ & $\%$ \\
\hline Rendah & 0 & 0 & 16 & 28.07 \\
Tinggi & 12 & 100 & 41 & 71.93 \\
Total & $\mathbf{1 2}$ & $\mathbf{1 0 0}$ & $\mathbf{5 7}$ & $\mathbf{1 0 0}$ \\
\hline $\begin{array}{l}\text { Sumber: Data } \\
\text { Responden }\end{array}$ & Hasil & Wawancara & kepada \\
\end{tabular}

Berdasarkan Tabel 14 digambarkan bahwa pada responden yang bekerja di PG Madukismo kondisi perumahan dan fasilitas yang dimiliki seluruhnya masuk dalam kategori tinggi yaitu sebesar 100\%, artinya responden memiliki perumahaan yang layak untuk ditempati oleh keluarganya. PG Madukismo juga memberikan jaminan sosial, salah satunya adalah rumah dinas untuk karyawan tetap. Rumah dinas yang diberikan oleh perusahaan selama bekerja dalam keadaan yang layak untuk ditinggali karyawan dan keluarganya. Kondisi rumah dinas yang diberikan oleh PG Madukismo memiliki atap yang terbuat dari genteng, dinding yang terbuat dari tembok dan lantai yang menggunakan keramik. Fasilitas yang diberikan dalam rumah dinas tersebut yaitu terdapat MCK dan sumber air dari sumur dan PAM, sedangakan untuk listrik ditanggung oleh karyawan yang menempati rumah tersebut. Bagi karyawan tetap yang tidak mengambil rumah dinas diberikan biaya kompensasi sebagai penggantinya

Masyarakat yang tidak bekerja di PG Madukismo 72\% masuk dalam kategori tinggi, yang artinya bahwa mayoritas masyarakat sudah memiliki perumahaan yang layak huni untuk keluarganya. Masyarakat Desa Tirtonirmolo mayoritas memiliki status rumah sendiri dan memiliki fasilitasnya sendiri, seperti sumber air dari sumur dan fasilitas MCK. Mayoritas masyarakat juga memiliki alat komunikasi seperti HP dan barang elektronik seperti TV, mesin cuci, kulkas serta kipas angin. Jenis kendaraan yang dimiliki oleh responden mayoritas sepeda dan sepeda motor. Karena di Yogyakarta tidak terdapat angkotan kota (angkot) sehingga masyarakat diharuskan memiliki 
kendaraan roda dua untuk memudahkan dalam melakukan kegiatan. Budaya yang masih melekat pada masyarakat dalam menggunakan sepeda untuk beraktivitas.

\section{Hubungan Persepsi Dampak Keberadaan PG Madukismo Terhadap Kesejahteraan Masyarakat}

Penelitian yang dilakukan oleh Rahayu (2014) menyatakan bahwa dampak suatu industri akan berhubungan dengan tingkat kesejahteraan rumah tangga. Bagian sebelumnya telah membahas tentang dampak keberadaan PG Madukismo terhadap masyarakat dan tingkat kesejahteraan masyarakat Desa Tirtonirmolo. Bagian ini akan membahas tentang Hubungan Persepsi Dampak Keberadaan PG Madukismo dan Tingkat Kesejahteraan Masyarakat yang tersaji dalam tabel 15 .

Tabel 15. Persepsi Dampak Keberadaan PG Madukismo dan Tingkat Kesejahteraan Masyarakat Desa Tirtonirmolo, Yogyakarta

\begin{tabular}{lllllll}
\hline Dampak & \multicolumn{4}{c}{ Kesejahteraan Masyarakat } \\
\cline { 2 - 7 } $\begin{array}{c}\text { Keberadaan } \\
\text { PG }\end{array}$ & \multicolumn{2}{c}{ Rendah } & \multicolumn{3}{c}{ Tinggi } & \multicolumn{2}{c}{ Total } \\
\cline { 2 - 7 } Madukismo & $\mathrm{n}$ & $\%$ & $\mathrm{n}$ & $\%$ & $\mathrm{n}$ & $\%$ \\
\hline Kecil & 17 & 24,64 & 21 & 30,43 & 38 & 55,07 \\
Besar & 5 & 7,25 & 26 & 37,68 & 31 & 44,93 \\
\hline Total & 22 & 31,88 & 47 & 68,12 & 69 & 100 \\
\hline Sumber: & Data & Hasil & Wawancara & kepada \\
& Responden & & & &
\end{tabular}

Data yang didapatkan dari hasil wawancara dan observasi dianalisis dengan menggunakan Uji rank Spearman. Data yang diuji adalah nilai total dampak keberadaan PG Madukismo dengan nilai total kesejahteraan masyarakat dari seluruh responden. Uji tersebut dilakukan menggunakan IBM SPSS Statistics 20 dengan hasil nilai kolerasi sebesar 0.000 . Dasar pengambilan keputusan, jika nilai sig. $<0.05$ maka berkorelasi, sedangkan jika sig. $>0.05$ tidak berkolerasi. Hasil uji rank spearman $0.000<0.05$ yang artinya berkolerasi. Hasil Correlation Coenfficient sebesar 0.440 dengan $\alpha 1 \%$. Kekuatan hubungan berada pada kategori 0.26-0.50 yang artinya korelasi cukup. Berdasarkan pembahasan diatas dapat disimpulkan bahwa variabel persepsi dampak keberadaan PG Madukismo memiliki hubungan yang cukup dengan variabel tingkat kesejahteraan masyarakat Desa Tirtonirmolo, Yogyakarta.

\section{KESIMPULAN DAN SARAN}

Keberadaan PG Madukismo memberikan dampak terhadap masyarakat Desa Tirtonirmolo, Kecamatan Kasihan, Kabupaten Bantul, Provinsi Daerah Istimewa Yogyakarta. Adanya PG Madukismo memberikan dampak positif yang diantaranya membuka peluang bekerja di PG Madukismo, membuka peluang usaha baru dan kegiatan sosial kepada masyarakat. Persepsi responden bekerja 
pada dampak keberadaan PG Madukismo masuk dalam kategori besar, namun untuk responden yang tidak bekerja masuk dalam kategori keduanya. Hal ini dipengaruhi oleh beberapa faktor salah satunya adalah jarak tempat tinggal responden dengan lokasi PG Madukismo.

Hasil penelitian terdapat perbedaan tingkat kesejahteraan masyarakat Desa Tirtonirmolo yang bekerja dengan yang tidak bekerja pada PG Madukismo, Yogyakarta. Responden yang bekerja memiliki tingkat kesejahteraan pada kategori tinggi, sedangkan untuk responden yang tidak bekerja di PG Madukismo masih ada responden yang masuk dalam kategori rendah. Hal ini terjadi salah satunya karena jenis pekerjaan responden yang akan berpengaruh terhadap pendapatan responden.

Hasil penelitian dapat disimpulkan bahwa persepsi dampak keberadaan PG Madukismo memiliki hubungan yang cukup dan searah dengan tingkat kesejahteraan masyarakat Desa Tirtonirmolo, Yogyakarta. Keberadaan PG Madukismo hanya memberikan dampak yang kecil kepada kesejahteraan masyarakat.

Adapun saran-saran yang dapat diajukan penulis kepada pihak-pihak terkait sesuai dengan hasil penelitian, yaitu:

1. PG Madukismo sebaiknya lebih memperhatikan kesejahteraan masyarakat Desa Tirtonirmolo secara keseluruhan tidak hanya dusun yang dekat dengan lokasi PG Madukismo saja, khususnya bagi lingkungan dan perekonomian masyarakatnya.

2. PG Madukismo sebaiknya lebih professional dalam perekrutan sumber daya manusia, sehingga masyarakat memiliki kesempatan untuk bekerja dan meningkatkan pendapatannya di PG Madukismo khususnya bagi masyarakat Desa Tirtonirmolo.

3. Masyarakat sebaiknya lebih mengembangkan sumber daya juga kreativitasnya agar dapat memiliki pekerjaan yang lebih baik ataupun menciptakan lapangan pekerjaan sehingga dapat meningkatkan kesejahteraannya.

\section{DAFTAR PUSTAKA}

Adianty, M. E. (2017). Dampak Industrialisasi Pedesaan terhadap Kesejahteraan Rumah Tangga. Institusi Pertanian Bogor.

Andriani, D. (2012). Strategi Pengembangan Agribisnis.

Ayuningtias, T. (2017). Dampak Industrialisasi Pedesaan terhadap Kesejahteraan Masyarakat di Desa Ciherang Pondok, Kecamatan Caringin, Kabupaten Bogor. 143- 
156.

Badan Pusat Statistika. (2015). Indikator Kesejahteraan Rakyat, Welfare indicators 2015.

Badan Pusat Statistika. (2019). Tujuan Pembangunan Berkelanjutan.

BkkbN. (2011). Batasan dan Pengertian $M D K$.

Kusumo, R. (2009). Peran Gender dalam Srategi Koping dan Pengambilan Keputusan serta Hubungannya dengan Kesejahteraan Keluarga Petani Padi dan Hortikultura di Daerah Pinggiran Perkotaan.

Marnelly, T. R. (2018). Dinamika Sosial Budaya Masyarakat Melayu Pesisir (Studi Pengelolaan Madu Sialang di Desa Rawa Mekar Jaya). Jurnal Antropologi: Isu-Isu Sosial Budaya, 19(2), 149.

PT Madubaru. (2007). Agro Wisata PT Madubaru PG-PS Madukismo.

Puspas, A. (2007). Ketahanan Keluarga Petani : Pengambilan Keputusan Istri dan Hubungannya dengan Kesejahteraan Keluarga [Skripsi] Program Studi Gizi Masyarakat
Dan Sumberdaya Keluarga. Fakultas Pertanian.

Rahayu, D. (2014). Dampak Keberadaan Agroindustri terhadap Kesejahteraan Masyarakat sekitar di Desa Sukamanah, Megamendung, Kabupaten Bogor. Institut Pertanian Bogor.

Siregar, S. (2013). Metode Penelitian Kuantitatif (1st ed.). Jakarta: Kencana Prenadamedia Group.

Subramanian, S. V. (2004). The Macroeconomic Determinants of Health. Annual Review of Public Health.

Sugiyono. (2012). Metode Penelitian Kuantitatif, Kualitatif dan $R \& D$. Bandung: Alfabeta, CV.

Suryana. (2000). Ekonomi Pembangunan: Problematika dan Pendekatan. Salemba Empat.

Todaro, M. P. (2000). Economics Development, Seventh Edition. New York: Pearson Education Limited. 